\title{
CUSTOMER SATISFACTION REVIEWED FROM PROBLEM BASED LEARNING, LEADERSHIP AND ALUMNI CONCERN
}

\author{
Slameto \\ Department of Educational Management \\ Satya Wacana Salatiga Christian University's, Indonesia \\ slameto@staff.uksw.edu
}

\author{
Bambang Suteng Sulasmono \\ Department of Educational Management \\ Satya Wacana Salatiga Christian University's, Indonesia \\ bambang.sulasmono@staff.uksw.edu
}

\author{
Krisma Widi Wardani \\ Teacher Education of Early Childhood Education \\ Satya Wacana Salatiga Christian University's, Indonesia \\ krisma.widi@staff.uksw.edu
}

\begin{abstract}
This study aims to measure the level of satisfaction of graduates of Satya Wacana Salatiga Christian University's Education Management Master Program and identify the determinants of user satisfaction of the graduates in question, which of them is leadership, environmental awareness and problem solving based lectures. Quantitative research data sources are alumni who work in one district, selected as many as 36 people. Data collected using self-rating scale consisting of 32 items that have been tested valid and reliable, reduced to 4 variables. Data were analyzed using SPSS 24 assisted analysis technique. The result showed that the level of customer satisfaction was at very high level. Found 1 model determinant that is leadership that give contribution equal to $35 \%$. Lecture quality variable of problem based learning and student awareness is removed from model.University-based quality improvement management based on student leadership becomes very critical.
\end{abstract}

Keywords: graduate of user satisfaction, leadership, environmental awareness, problem-based learning

\section{INTRODUCTION}

The need for the importance of quality education has now become an awareness of the Indonesian nation (Barlian, 2016; Samani, 2015; Walansendow, Mulyadi, \& Hamel, 2016); Education is a very important need. Because education is the process of developing or forming the potential of learners so that they are able to become the heir and development of a nation's culture. In Law No. 20 year 2003 article 1 mentioned that education is a conscious and planned effort to create an atmosphere of learning and learning process so that learners actively develop their potential to have spiritual power of religion, self-control, personality, intelligence, noble character, Skills needed of him, society, nation and state.

In the paradigm of integrated quality management, customer satisfaction is an important indicator of the quality of education; The higher the level of customer satisfaction is the quality assurance of the relevant education (Indana, 2017; Ruhadi, 2011; Zahroh, 2015). There are two categories of customers: internal customers and external customers; One important dimension of external customers is user satisfaction graduates (Ratih, 2011; Ratmini, Kencana, 2008).

The Master Degree Program of Satya Wacana Salatiga Christian Education Management feels compelled to participate in quality improvement efforts such as the above paradigm; Therefore conducting an alumni search which has now become an elementary school teacher, principal and or school supervisor in Temanggung District. This search result will be very useful for improving the curriculum in order to continuously improve the quality of the Master Program in Education Management. Given the many factors that affect the user's satisfaction of graduates (Agustina, 2016), it is necessary to find and select the determinants or determinants. In the educational perspective as a system, the results (user satisfaction graduates) are directly influenced by the process (leadership, environmental concern and problem solving-based lectures) (see Frost, 2003).

The problems in this study were formulated: (1) high level of satisfaction level of graduates of Satya Wacana Salatiga Christian University's Education Management Master Program, and (2) among factors, leadership, environmental awareness and problem solving-based lectures) Which determines the satisfaction of graduate users? Many understandings about the quality of education; One of which is based on a system approach, so that quality is found in terms of inputs (students, lecturers, support staff and infrastructure), process quality (lectures and other activities) and quality of output that are competent and brilliant alumni of the future (Sahney, et al. , 2004). Graduate users are external parties who are consumers for the output of educational institutions. External parties can be government institutions, private or individual. Users of graduates, both individuals and institutions will always assess the performance of university graduates as their employees.

Graduate user satisfaction is often reviewed from eight aspects: (1) the ability to actualize themselves as group members in the workplace environment, (2) Responsibility in carrying out the work, (3) the ability to develop professionalism in the field of work, (4) the ability to work well with colleagues, Superiors and subordinates, (5) ability to adapt to changes in ICT development, (6) mastery of concepts, knowledge, and skills in the field of work, (7) the ability to develop the concept of the field of science and skills in the workplace, and (8) skills in linking concepts and substances knowledge and skills in the field of employment (Sudirtha, 2013). 
Leadership is seen as a very important factor for the effectiveness of the organization, and even affect virtually all human life (Handoyo, 2011). Leadership is the ability to influence a person, so that they act and behave in accordance with the goals to be achieved by the leader. Leadership is one of the important factors in achieving organizational goals (Robbins, 1996). Leadership is a complex process in which a person influences others to achieve a mission, a task, or a goal, and directs the organization in a way that makes it more cohesive and more sensible; Leadership ability is essentially the ability to influence the behavior of a person or group of people to achieve certain goals effectively at a pleasant working environment (Wirjana and Supardo, 2006). The indicators of leadership is: to provide support, develop, recognize, reward, manage conflict and build networks (Wibowo, Machfudz, \& Sunaryo, 2015).

Learning is a process of interaction of learners with educators and learning resources in a learning environment (Depdiknas, 2003). In the process is expected to occur interaction between learners with educators or among fellow learners themselves. Problem Based Learning is a learning model that can provide an active learning conditions for students. Problem Based Learning is a learning process that is the starting point of learning based on real life problems, then students are stimulated to study problems based on knowledge and experience they have previously (prior knowledge) so that the prior knowledge will form new knowledge and experience. Discussions with the use of small groups is the main point in the implementation of Problem Based Learning (Zulharman, 2007). Steps Problem Based Learning are: (1) present or identify problems, (2) develop a plan to solve the problem, (3) implement a plan to solve the problem, and (4) evaluating the results of the implementation plan of solving (Purnomo \& Wijanarka, 2017).

Caring is a form of attention one gives to others. Sense of concern is what is experienced by the heart / mind to give attention to others (Fonny and Mayasari, 2013). Adam Smith (Emannulisa, 2015) considers that caring / sympathetic attitude is an important factor in social behavior. It is further said that caring / sympathy describes a sense of togetherness when one is seeing another person experiencing an extraordinary emotional state. Through imagining activities, a person can put himself in the situation faced by others, accept as it is and reflect on him. Caring people are those who do something in order to give change, and inspiration to the surrounding environment. What this does is expected to encourage or help the conditions around it. Caring is caring, caring and ignoring.

This study aims to measure the level of satisfaction of graduate users of SWCU MP Program and identify the determinants of user satisfaction of the graduates in question, which are among the leadership, environmental concerns and problem solving based lectures. The results of this research will be useful in the management of the curriculum of the Master
Program in Management of Education; With the discovery of the determinants in question, it will be done data-based curriculum empowerment, so there is a guarantee of success in efforts to improve quality.

\section{METHODS}

Based on the formulation of the proposed problem, this quantitative research includes research that is causality. The inferential method in quantitative research reveals a relationship of duality between two or more variables that can explain the symptoms, examine the effect of $X$ variable (leadership, environmental awareness and problem solving-based lectures) on Y (satisfaction of graduates of Satya Wacana Salatiga Christian University's Education Management Master Program); and then find the determinant variable or its determinant. This research was conducted in the second semester of 2016/2017.

\section{Participant}

This research was conducted based on the graduate user's evaluation of the alumni of the Satya Wacana Salatiga Christian University Management Master's Degree Program which graduated in $2014 / 2015$ who is now an elementary school teacher or principal in Temanggung District. The SWCU MP Program Alumni consists of 36 people spread across 30 schools; Users of graduates in this study are principals where alumni become teachers and school supervisors where alumni become principals.

\section{Data Analysis Instruments and Techniques}

The data of this research is quantitative data in the form of numbers; Ordinal data is data expressed in terms of categories and / or ratings. Ordinal scale used is a ranking scale consisting of statements and answers with low, medium, high and very high in accordance with the purpose of measurement. Data on graduate user satisfaction is captured using an instrument consisting of 8 items in the form of scale; Filled by direct supervisors where the alumni work. Data 3 predictor variables were collected through a self-rating scale consisting of 26 items that have been proven to be valid and reliable; The validity score is 0.314 to 0.506 with the Cronbach Alpha $=0.632$ reliability index. Data of each variable was analyzed using frequency distribution, followed by multiple linear regression analysis with step-wise model.

Before analyzing multiple linear regression with SPSS, ordinal data was converted into interval data first, then the researchers developed a relationship model (causal model). The independent variable independent variable against the dependent variable is tested by $F$ test at the 0.05 level. This calculation is done with SPSS version 24. In model testing, the determinant coefficient of the independent variable to the dependent variable is calculated. In this study, the results of the calculation of the coefficient of determination of the independent variable on the dependent variable for the coefficient of adjusted $\mathrm{R} 2$. If the significance of $\mathrm{r}$ is less than or equal to 0.05 , then this model was significant, because $\mathrm{X}$ affects $\mathrm{Y}$, amounting coefficient adjusted R 2 . 


\section{Statistical hypothesis}

On an ordinal scale, Satya Wacana Salatiga Satya Wacana Christian University's Satya Wacana Education Management Master Degree graduate, there is one dominant level among the four categories: low, medium, high and very high. Among the independent variables, have a positive and significant effect on user satisfaction graduates / alumni of Satya Wacana Salatiga Christian University Management Education Program. In other words, the regression coefficient predictor determinants (b 1) is positive and significant. The proposed statistical hypothesis is:

$\mathrm{H}_{0}: \mathrm{b}_{1}=0$ (no effect predictor of user satisfaction graduate).

$\mathrm{H}_{1}: \mathrm{b}_{1} \neq 0$ (no effect predictor of user satisfaction of graduates).
The impact of a single or double predictor found can be determined by looking at the value of $b$ in the corresponding variable. In addition, the importance of $b$ value will be tested by t-test. T significance can be seen at its value. If $b$ is positive, and $t$ is significant at an error rate of less than 0.05 , the hypothesis ( $\mathrm{H} 1)$ will be accepted.

\section{RESULTS}

After the data captured using self-rating scale consisting of eight items for the graduates and 24 items were reduced to three, and then analyzed by descriptive assisted SPSS for windows version 24 is obtained in the form of Table 1.

Table 1

Statistical Index of Research Variables

\begin{tabular}{lccccc}
\hline \multicolumn{1}{c}{ Variable } & Mean & Median & Std. Deviation & Minimum & Maximum \\
\hline $\mathrm{X}_{1}$ Problem based learning & 3.4286 & 3.0000 & .51355 & 3.00 & 4.00 \\
$\mathrm{X}_{2}$ Leadership & 3.3333 & 3.0000 & .48795 & 3.00 & 4.00 \\
$\mathrm{X}_{3}$ Concern & 3.1333 & 3.0000 & .51640 & 2.00 & 4.00 \\
Y User satisfaction graduates & 3.4667 & 3.0000 & .51640 & 3.00 & 4.00 \\
\hline
\end{tabular}

Based on the results of descriptive analysis presented PADSA Table 1 above, the majority of respondents (alumni of the Management Program of Education Christian University Satya Discourse Salatiga) has a quality assessment of lectures Problem based learning $\left(\mathrm{X}_{1)}\right.$ at the level of good, even tend to be very good, but it also develops leadership $\left(X_{2}\right)$ at a high level, Besides developing awareness / sympathy students in order to make a change, and inspiring the surrounding environment $\left(\mathrm{X}_{3}\right)$ at a high level, and user satisfaction of graduates / alumni (Y) at very high.

Hypothesis testing

Subsequent analysis is to determine whether the three independent variables $\left(X_{1-3}\right.$ effect on user satisfaction graduates / alumni of the University of Education Management Master Program Kristen Satya Wacana Salatiga (Y). If so, how many models are there, and how much does it affect? Regression analysis results are in 3 tables below.

\begin{tabular}{|l|c|c|c|c|}
\hline Model & R & R Square & Adjusted R Square & Std. Error of the Estimate \\
\hline 1 & $.632^{\text {a }}$ & .400 & .350 & .41833 \\
\hline
\end{tabular}

A. Predictors: (Constant), Leadership

Based on the results of hypothesis testing through regression analysis as presented in table 2 above, it was obtained only 1 Model only; Model 1 Leadership $\left(\mathrm{X}_{2)}\right.$ effect on user satisfaction graduates / alumni of the University of Education Management Master Program Kristen Satya Wacana Salatiga (Y): obtained $\mathrm{R}=0.632$ and Adjusted R Square $=0.350$ or $35 \%$. Thus the hypothesis which states there are determinants of satisfaction of alumni of Education Management Master Program of Satya Wacana Christian University of Salatiga supported data.

\begin{tabular}{|l|l|c|c|c|c|c|}
\hline \multicolumn{2}{|l|}{ Model } & Sum of Squares & Df & Mean Square & F & Sig. \\
\hline \multicolumn{1}{|c|}{} & Regression & 1.400 & 1 & 1.400 & 8.000 & $.015^{\text {b }}$ \\
\cline { 2 - 8 } & Residual & 2.100 & 12 & .175 & & \\
\cline { 2 - 8 } & Total & 3.500 & 13 & & & \\
\end{tabular}

A. Dependent Variable: User satisfaction graduates

B. Predictors: (Constant), Leadership

Based on table 3 anova as above, apparently obtained only 1 Model; Model 1 Model of Leadership $\left(\mathrm{X}_{2}\right.$ ) effect on user satisfaction graduates / alumni of the University of Education Management Master Program Kristen Satya Wacana Salatiga (Y): obtained $\mathrm{F}=8.000$ at a significance level of 0.015 . Thus only one predictor variable that is influential leadership (positive and significant) becomes the determinant of the satisfaction of the graduate / alumni of Satya Wacana Salatiga Christian University Management Education Program. Both variables: the quality of lectures problem based learning $\left(\mathrm{X}_{1)}\right.$ and concern / sympathy students in order to make a change and inspiration to the surrounding environment $\left(\mathrm{X}_{3}\right.$ ) were excluded from the model; In other words the quality of lectures problem based learning and awareness / 
sympathy of students in order to provide change and inspiration to the surrounding environment does not become a determinant of the satisfaction of graduate / alumni of Satya Wacana Salatiga Christian University Education Management Education Program.

\section{DISCUSSION}

The results of this study indicate that the level of customer satisfaction in this case graduate users over the work of alumni of Management Education Program Satya Christian University Satya Wacana Salatiga on very high. This is in contrast to the findings Setyaningsih \& Abrori (2013) which states that the $9^{\text {th }}$ dimension examined still show a negative gap value. This means that overall users have not been satisfied with the performance of alumni; Of the nine dimensions in question, organizational skill and leadership dimensions have the largest gap of 0.82. This indicates that both of these aspects need serious attention in future lectures.

The results show that the level of leadership of the alumni of the Salatiga SWCU Education Management Program is at a high level; Nevertheless, there are still some things that need to be considered and used as input for the improvement of the curriculum in the future in order to develop the leadership of the alumni of Education Management Program of SWCU Salatiga. There are still some things related to the graduates kususnya ability to develop professionalism in the field of employment and the ability to adapt to changes in the development of science and technology (Sudiartha, 2013).

This research was found to have 1 model, the leadership becomes the determinant of the satisfaction of graduate / alumni of Satya Wacana Salatiga Christian University Management Education Program; Leadership influence (positive and significant) to the satisfaction of graduate / alumni users by $35 \%$. These findings concur with those of Edison (2012) which states that there are significant leadership on Customer satisfaction of $27.62 \%$.

Leadership is seen as a very important factor for organizational effectiveness, even affecting almost all human life (Handoyo, 2011). Leadership is the ability to influence a group to achieve a vision or purpose. Leadership is the ability to influence a person, so that they act and behave in accordance with the goals to be achieved by the leader.Leadership is one of the important factors in achieving organizational goals (Robbins, 1996). Leadership, to this day is still considered very important; Frost (2003) stresses that due to the leadership crisis, many people suffering, burn-outs, who can not enjoy life in their jobs, and many costs incurred to treat emotional pain in the workplace. There is a great need today to conduct leadership education for future generations, including leadership through higher education institutions.

Higher education has a characteristic that requires a certain leadership (Handoyo, 2011). A person who occupies a leadership position in the managerial of an organization (including higher education) has an important role. The roles are: as a catalyst, as a facilitator, as a problem solver, as a source link, and as a communicator. The success of one's leadership can be measured or marked by four things: moral, discipline, esprit de corps and finesse (Faisal Burhanudin, 2012/2013). Given such an important role of leadership, let alone education management courses, then one form / indicator of the success of the study program concerned is how high levels of leadership of graduate students; So that all facilities and infrastructure are strived to support student achievement while lecturing takes place as the basis of management of study program concerned. In the perspective of educational management, the quality of alumni leadership is one of the most important predictors of higher education quality; Therefore it is necessary to continuously strive to improve the quality management of Higher Education based on student leadership which has been missed from the quality management design of PT.

\section{CONCLUSIONS AND RECOMMENDATIONS}

The results of this study indicate that the level of customer satisfaction is the graduate users of the alumni of Master Satya Wacana Salatiga Christian Education Management Program is at a very high level. This research also produces 1 model determinant of leadership influence toward the graduation / alumni user satisfaction by $35 \%$. The two variables are: the quality of lecture problem based learning and the students' concerns / sympathy in order to give change and inspiration to the surrounding environment is removed from the model; In other words, these two variables do not become the determinant of user satisfaction graduates / alumni of Satya Wacana Salatiga Christian University Management Education Program.

University-based quality improvement management based on student leadership becomes very important. Therefore, the effort to develop the leadership of the SWCU Education Management Program alumni of Salatiga needs to improve the curriculum that facilitates the development of organizational dimension and student professionalism in the field of work and the ability to adapt to changes in the development of science and technology.

\section{REFERENCE}

[1] Agustina, Dian. 2016. Analisis Faktor Konfirmatori pada Faktor yang Mempengaruhi Kepuasan Pengguna Lulusan Matematika UNIB. Proceeding Semirata Bidang MIPA 2016; BKS-PTN Barat, Palembang, May 22-24.

[2] Barlian, U. C. 2016. Kebijakan Pengelolaan Dana Pendidikan Tingkat Sekolah dalam Konteks Otonomi Daerah. An-Nidzam Jurnal Manajemen Pendidikan dan Studi Islam, 3(2).

[3] Edison, A. 2012. Pengaruh Kepemimpinan, Keterlibatan Pekerja, Perbaikan Terus-menerus terhadap Kepuasan Pelanggan (Studi pada Industri Tekstil di Kota-Kabupaten Bandung Jawa Barat). Retrieved December 27, 2016, from http://repository.widyatama.ac.id/xmlui/handle/123456 $789 / 1909$. 
[4] Emannulisa, A. 2015. Pengaruh Sosial Ekonomi terhadap Perilaku Pengelolaan Sampah Rumah Tangga Kecamatan Sawangan Kota Depok. Retrieved December 27, 2016, from repository.ipb.ac.id/ bitstream/123456789/76775/1/H15aem.pdf.

[5] Faisal Burhanudin. 2012/2013. Faktor Kepemimpinan. Retrieved December 27, 2016, from https://www.academia.edu/7119898/.

[6] Fonny, M. 2013. Perancangan Iklan Layanan Masyarakat sebagai Penyadaran Rasa Kepedulian pada Panti Asuhan Al-Rifdah Semarang. Thesis. Bandung: Pajajaran University.

[7] Frost, P. J. 2003. Toxic emotion at work: How compassionate managers handle pain and conflict. Boston: Harvard Business School Press.

[8] Handoyo, S. 2011. Pengukuran servant leadership sebagai alternatif kepemimpinan di institusi pendidikan tinggi pada masa perubahan organisasi. Makara HubsAsia, 8(3).

[9] Indana, N. 2017. Implementasi Total Quality Management (TQM) dalam Meningkatkan Mutu Pendidikan. Al-idaroh: Jurnal Studi Manajemen Pendidikan Islam, 1(1), 62-86.

[10] Purnomo, D. H., \& Wijanarka, B. S. (2017). Problem Based Learning Untuk Meningkatkan Kompetensi Gambar Manufaktur Di SMK N 2 Wonosari. Jurnal Pendidikan Vokasional Teknik Mesin, 5(3), 207-214.

[11] Ratih, I. A. D. K. 2011. Upaya Pengembangan Mutu Pendidikan Poltekkes Denpasar Berdasarkan Kepuasan Pengguna Lulusan. Jurnal Skala Husada, 196.

[12] Ratmini, N. K., Kencana, I. G. S., \& Arini, N. W. 2008. Tingkat Kepuasan Pengguna Lulusan Jurusan Kesehatan Gigi (JKG) Poltekkes Denpasar di Bali Tahun 2008. Jurnal Skala Husada, 105.

[13] Robbins, S. P. 1996. Organizational Behavior: Concept Controversies Applications. Jakarta: PT Prenhallindo.

[14] Ruhadi, R. 2011. Pengembangan Kurikulum di Sekolah Dasar Islam Terpadu (Studi Situs di SDIT Assalamah Ungaran Kab. Semarang). Dissertation. Surakarta: Universitas Muhammadiyah Surakarta.

[15] Sahney, et al. 2004. A Servqual and QFD Approach to Total Quality Education, a Student Perspective. International Journal of Productivity and Performance Management. Vol. 53 No. 2 , 2004: 143-166

[16] Samani, M. 2015. Kesadaran Pendidikan Meningkat. Retrieved December 27, 2016, from http://muchlassamani. blogspot. co.id/2015/07/kesadaran-pendidikan-meningkat.html.

[17] Setyaningsih, I., \& Abrori, M. 2013. Analisis Kualitas Lulusan Berdasarkan Tingkat Kepuasan Pengguna Lulusan. Jurnal Ilmiah Teknik Industri, 12(1), 73-82.

[18] Sudarta, I. W., Dharmana, E., \& Santoso, A. 2014 Pengaruh Loyalitas dan Kepuasan Terhadap Kinerja Perawat Dalam Asuhan Keperawatan Pasien Rawat Inap Rumah Sakit Swasta di Yogyakarta. Jurnal Manajemen Keperawatan PPNI, 2(1), 22-29.

[19] Sudirtha, I. G. 2013. Profil Alumni Fakultas Teknik Dan Kejuruan Universitas Pendidikan Ganesha Ditinjau dari Keterserapannya di Dunia Kerja. Jurnal Pendidikan Teknologi dan Kejuruan, 10(1).

[20] Walansendow, P. I., Mulyadi, N., \& Hamel, R. 2016. Faktor-faktor yang Mempengaruhi Tingkat Prestasi Anak Usia Sekolah di SD GMIM Tumpengan Sea Dua Kecamatan Pineleng. Jurnal Keperawatan, 4(2).

[21] Wibowo, B., Machfudz, M., \& Sunaryo, H. 2015. Pengaruh Karakteristik Pekerjaan, Motivasi dan Kepemimpinan Terhadap Kinerja Pegawai di Kantor Imigrasi Kelas I Malang. Warta Ekonomi, 4(2).

[22] Zahroh, A. (2015). Total Quality Management: Capaian Kualitas Output Melalui Sistem Kontrol Mutu
Sekolah. Cendekia: Journal of Education and Teaching, 9(1), 79-94.

[23] Zulharman. 2007. Problem Based Learning (PBL). Retrieved December 27, 2016, from https://zulharman79.wordpress.com/ 2007/07/15/. 